Article

\title{
Bimetallic synergistic $\mathrm{Au} / \mathrm{CuO}$-hydroxyapatite catalyst for aerobic oxidation of alcohols
}

\author{
Tao Tian, Ying Liu, Xungao Zhang* \\ College of Chemistry and Molecular Sciences, Wuhan University, Wuhan 430072, Hubei, China
}

\section{A R T I C L E I N F O}

Article history:

Received 10 February 2015

Accepted 27 March 2015

Published 20 August 2015

\section{Keywords:}

Heterogeneous catalysis

Gold-copper bimetallic catalyst

Aerobic oxidation of alcohols

Hydroxyapatite

Reusability

\section{Introduction}

Liquid-phase oxidation of alcohols to the corresponding ketones or aldehydes is important in organic functional group conversion reactions [1]. Traditionally, stoichiometric oxidants such as dichromate and permanganate have been used in the oxidation of alcohols [2-5]. However, excessive use of these stoichiometric oxidants raises environmental and safety concerns. In addition, many by-products are generated because of over oxidation. In terms of cost saving and environmental protection, new routes to aldehydes and ketones using benign oxidizing agents such as organic peroxides, hydrogen peroxide, and molecular oxygen are of significant interest [6-8]. Nanomaterials based on noble metals such as $\mathrm{Pd}, \mathrm{Au}, \mathrm{Pt}$, and $\mathrm{Ru}$ have been widely studied as potential catalysts [9-12].

$\mathrm{Au}$ was considered to be an inert material until Haruta et al. $[13,14]$ showed that well-dispersed $\mathrm{Au}$ nanoparticles (NPs, below $10 \mathrm{~nm}$ ) supported on $\mathrm{TiO}_{2}$ show high activity in the low-temperature CO oxidation. In the last two decades, nanosized $\mathrm{Au}$ catalysts have attracted much attention because of their high catalytic activity in various reactions $[15,16]$. Recently, bimetallic Au catalysts have been found to have better catalytic activity and selectivity than monometallic catalysts, because of their tunable and synergistic properties; for example, $\mathrm{Au}-\mathrm{Pd} / \mathrm{TiO}_{2}$ catalysts have been used in the oxidation of primary carbon-hydrogen bonds in toluene [17], oxidation of primary alcohols [18], cinnamaldehyde hydrogenation [19], and direct hydrogen peroxide synthesis [20]. Zhao et al. [21] reported that the stability and catalytic lifetime of a $\mathrm{Au} / \gamma-\mathrm{Al}_{2} \mathrm{O}_{3}$ catalyst could be improved by the addition of Bi. Zhang et al. [22] found that $\mathrm{Au}$ in cooperation with Co gave superior catalytic activity and long-term stability in acetylene hydrochlorination.

Supported bimetallic $\mathrm{Au}-\mathrm{Cu}$ catalysts have been widely used

\footnotetext{
*Corresponding author. Tel/Fax: +86-27-68752136; E-mail: xgzhang66@whu.edu.cn This work was supported by Natural Science Foundation of Hebei Province of China (2013CFB291). DOI: 10.1016/S1872-2067(15)60854-3 | http://www.sciencedirect.com/science/journal/18722067 | Chin. J. Catal., Vol. 36, No. 8, August 2015
} 
in $\mathrm{CO}$ preferential oxidation [23], $\mathrm{CO}_{2}$ reduction [24], hydrogenation of cinnamaldehyde [25], and gas-phase oxidation of benzyl alcohol [26]. Recently, Li et al. [27] reported that silica-supported Au-Cu alloy NPs showed good activity and selectivity for aldehydes in liquid-phase oxidation of alcohols under mild and base-free conditions, but rigorous post-processing such as reduction with $\mathrm{H}_{2}$ at $550{ }^{\circ} \mathrm{C}$ was necessary for catalyst recovery. A CuO-supported Au catalyst with high selectivity and activity for benzyl alcohol oxidation under mild conditions has been reported [28]. In this study, we prepared and characterized $\mathrm{Au}$ supported on CuO-modified hydroxyapatite $(\mathrm{Au} / \mathrm{CuO}-\mathrm{HAP})$, and investigated its catalytic properties in the oxidation of alcohols. The Au/CuO-HAP performance was better than those of monometallic Au/HAP and CuO-HAP, and it had excellent recyclability. Various aromatic alcohols were efficiently converted to their corresponding aldehydes or ketones over $\mathrm{Au} / \mathrm{CuO}$-HAP under aerobic conditions.

\section{Experimental}

All reagents were analytical grade and purchased from the Sinopharm Chemical Reagent Co., Ltd. They were used without further purification unless otherwise specified. Deionized water was used in all experiments.

\subsection{Preparation of HAP and CUO-HAP supports}

HAP was prepared as follows. Phosphoric acid aqueous solution (300 mL, $0.1 \mathrm{~mol} / \mathrm{L}$ ) was added dropwise to an aqueous suspension ( $300 \mathrm{~mL}$ ) of calcium hydroxide (3.71 g, $0.05 \mathrm{~mol}$ ) under vigorous mechanical stirring. The dropping speed was controlled at $4 \mathrm{~mL} / \mathrm{min}$, the temperature of the suspension solution was set at $80^{\circ} \mathrm{C}$, and the $\mathrm{pH}$ of the suspension solution was adjusted to 9.0 with aqueous ammonia. After addition of the phosphoric acid solution, the mixture was stirred at $80{ }^{\circ} \mathrm{C}$ for $3 \mathrm{~h}$. The resulting precipitate was collected by filtration and washed with deionized water. The solid was dried at $105{ }^{\circ} \mathrm{C}$ overnight, and then calcined at $500{ }^{\circ} \mathrm{C}$ for $3 \mathrm{~h}$.

The CuO-HAP support was prepared by dropwise addition of an aqueous solution (300 $\mathrm{mL}$ ) of phosphoric acid (3.68 g, purity $85 \%$ ) and copper(II) chloride dihydrate $(0.571 \mathrm{~g})$ to an aqueous suspension (300 $\mathrm{mL}$ ) of calcium hydroxide (3.71 g), with vigorous mechanical stirring; the molar ratio of $\mathrm{Ca}+$ $\mathrm{Cu}) / \mathrm{P}$ was set at 1.67. The subsequent procedures were the same as those for HAP preparation. The resulting product was denoted by $\mathrm{CuO}-\mathrm{HAP}$.

\subsection{Preparation of $A u / H A P$ and $\mathrm{Au} / \mathrm{CuO}-\mathrm{HAP}$ catalysts}

The $\mathrm{Au} / \mathrm{HAP}$ and $\mathrm{Au} / \mathrm{CuO}-\mathrm{HAP}$ catalysts were prepared using the homogeneous deposition-precipitation method developed by Zanella et al. [29], using urea as the precipitating agent. HAP or CuO-HAP ( $0.5 \mathrm{~g}$ ) was added to an aqueous solution (20 $\mathrm{mL})$ of $\mathrm{HAuCl}_{4} \cdot 4 \mathrm{H}_{2} \mathrm{O}\left(5.3 \times 10^{-3} \mathrm{~mol} / \mathrm{L}\right)$ and urea $(0.84 \mathrm{~mol} / \mathrm{L})$. The suspension was heated to $90{ }^{\circ} \mathrm{C}$ and stirred for $4 \mathrm{~h}$. The solid was separated by centrifugation and washed with deionized water until no chloride ions were detected (using $\mathrm{AgNO}_{3}$ solution) in the supernatant. The solid was dried at $90{ }^{\circ} \mathrm{C}$ overnight and calcined at $300{ }^{\circ} \mathrm{C}$ for $4 \mathrm{~h}$ in air flow $(30 \mathrm{~mL} / \mathrm{min}$ ). The obtained purple catalysts were denoted by $\mathrm{Au} / \mathrm{HAP}$ and $\mathrm{Au} / \mathrm{CuO}-\mathrm{HAP}$.

\subsection{Catalyst characterization}

The $\mathrm{Au}$ and $\mathrm{Cu}$ contents of the catalysts were determined using atomic absorption spectrometry (AAS; Perkin-Elmer PEAA800). The specific surface areas of the catalysts were determined from their $\mathrm{N}_{2}$ adsorption-desorption isotherms at $-196^{\circ} \mathrm{C}$ by the Brunauer-Emmett-Teller method, using a Tristar II 3020 V1.02 instrument (Micromeritics Instrument Corporation, USA). The pore size distributions were obtained from the desorption branch of the $\mathrm{N}_{2}$ adsorption-desorption isotherms using the Barrett-Joyner-Halenda (BJH) method. The crystal structure of the catalysts were examined using powder X-ray diffraction (XRD; X'Pert Pro, PANalytical, $\mathrm{Cu} K_{\alpha}$ radiation $(\lambda=0.15406 \mathrm{~nm})$, operated at $40 \mathrm{~mA}$ and $40 \mathrm{kV})$. Transmission electron microscopy (TEM) and high-resolution TEM (HRTEM) were performed using a JEOL JEM-2010-HR microscope operated at $200 \mathrm{kV}$. Before the TEM experiments, the samples were ultrasonically dispersed in ethanol and transferred to a $\mathrm{Cu}$ grid coated with a holey carbon film. The chemical states of the surface elements were determined using X-ray photoelectron spectroscopy (XPS; ESCALAB 250Xi, Thermo Fisher) with monochromic Al $K_{\alpha}$ radiation; all binding energies were calibrated using the $\mathrm{C} 1 s$ line at $284.8 \mathrm{eV}$.

\subsection{Catalytic reaction}

The alcohol aerobic oxidations were performed in a bath-type reactor under oxygen $(101.3 \mathrm{kPa})$. In a typical reaction, a $25 \mathrm{~mL}$ three-necked round-bottomed flask containing alcohol ( $3 \mathrm{mmol}$ ), $\mathrm{K}_{2} \mathrm{CO}_{3}$ (1 mmol), a certain amount of catalyst, and $p$-xylene $(10 \mathrm{~mL})$ was kept at $120{ }^{\circ} \mathrm{C}$, with magnetic stirring $(1200 \mathrm{r} / \mathrm{min})$. Oxygen was flowed into the suspension at a rate of $20 \mathrm{~mL} / \mathrm{min}$. The liquid products were obtained by centrifugation, and then analyzed using a gas chromatograph (GC-1690, Hangzhou Jiedao Technology Instrument Co., Ltd) equipped with a flame ionization detector (FID) and an AT OV-1701 capillary column, to determine the conversion and selectivity. Gas chromatography-mass spectrometry (GC-MS; 450GC-320MS, Varian) was used to confirm the product compositions.

The catalysts were recovered by centrifugation, washed alternately with ethanol and water several times, and dried at 90 ${ }^{\circ} \mathrm{C}$ overnight. The recovered catalyst was used to investigate the recycling performance under the same reaction conditions.

\section{Results and discussion}

\subsection{Catalyst characterization}

The $\mathrm{N}_{2}$ adsorption-desorption isotherms of $\mathrm{Au} / \mathrm{HAP}$, $\mathrm{CuO} / \mathrm{HAP}$, and $\mathrm{Au} / \mathrm{CuO}-\mathrm{HAP}$ are shown in Fig. 1(a). The relative pressure was set in the range 0.01-1.0. The surface areas of 
$\mathrm{Au} / \mathrm{HAP}, \mathrm{CuO}-\mathrm{HAP}$, and $\mathrm{Au} / \mathrm{CuO}-\mathrm{HAP}$ were 53.8, 50.8, and 53.7 $\mathrm{m}^{2} / \mathrm{g}$, respectively. There were no significant differences among the specific surface areas, and sickle-shaped $\mathrm{N}_{2}$ adsorption-desorption isotherms were observed for all three catalysts. Fig. 1(b) shows that the major peak for the three catalysts was located at $27 \mathrm{~nm}$. However, after loading with $\mathrm{Cu}$ species, a shoulder peak appeared at about $39 \mathrm{~nm}$ for both $\mathrm{CuO}-\mathrm{HAP}$ and $\mathrm{Au} / \mathrm{CuO}-\mathrm{HAP}$, indicating that the $\mathrm{Cu}$ species altered the porous structure; these results are consistent with those in the literature [30].

Fig. 2 shows the TEM and HRTEM images of $\mathrm{Au} / \mathrm{HAP}$, $\mathrm{CuO}-\mathrm{HAP}$, and $\mathrm{Au} / \mathrm{CuO}-\mathrm{HAP}$ and their metal particle size distribution diagrams. Fig. 2(a) shows that the Au NPs are well dispersed on nanosized HAP, with an average diameter of 3.8 $\mathrm{nm}$. The measured interplanar distances of 0.235 and $0.343 \mathrm{~nm}$ correspond to the spacing of the (111) plane of face-centered cubic Au NPs (PDF No. 04-0784) and the spacing of the (002) plane of HAP (PDF No. 09-0432), respectively (Fig. 2(d)). It is clear from Fig. 2(b) that a large number of small particles of average diameter $(2.7 \mathrm{~nm})$ are uniformly dispersed on the support; most of the particles are of size 2 to $3.5 \mathrm{~nm}$. The lattice spacing of $0.232 \mathrm{~nm}$ corresponds to the (111) plane of monoclinic CuO NPs (PDF No. 48-1548; Fig. 2(e)). The TEM and HRTEM images of $\mathrm{CuO}$-HAP confirm that a large number of $\mathrm{CuO}$ NPs were generated during support preparation, and that the support has the typical HAP structure, although some $\mathrm{Cu}^{2+}$ ions
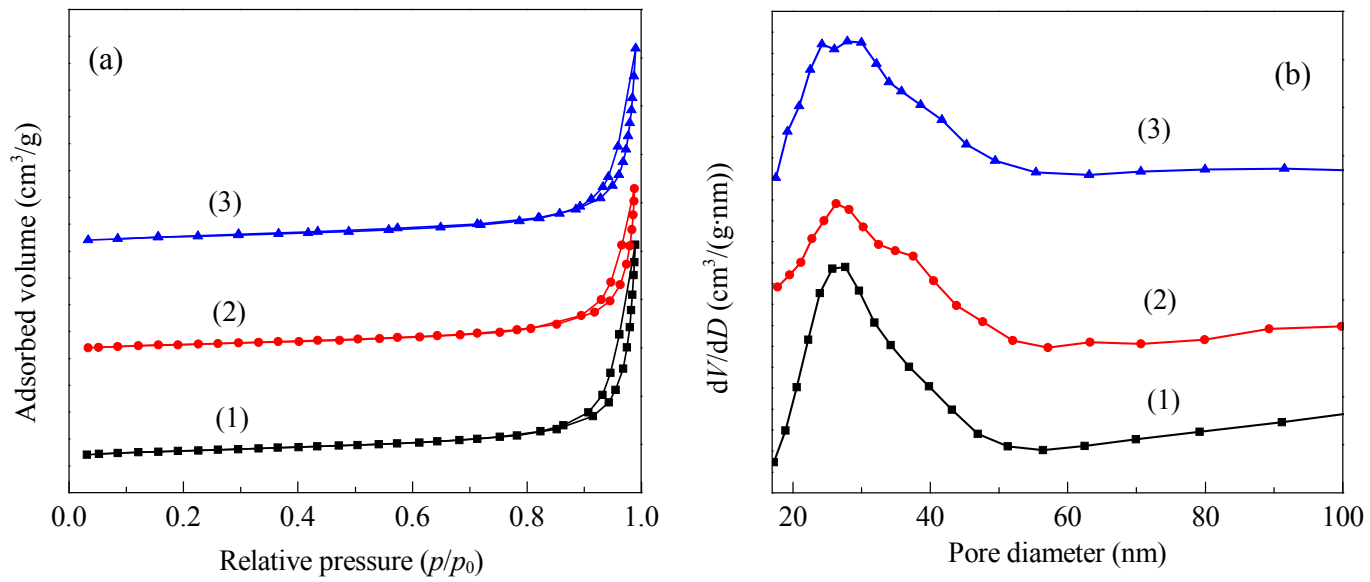

Fig. 1. $\mathrm{N}_{2}$ adsorption-desorption isotherms (a) and BJH pore size distributions (b) of Au/HAP (1), CuO/HAP (2), and Au/CuO-HAP (3).

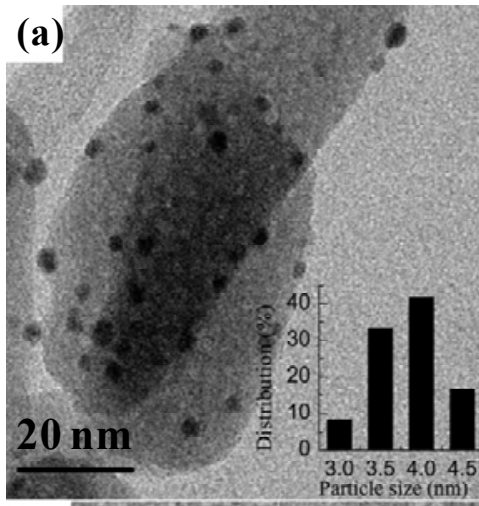

(d)

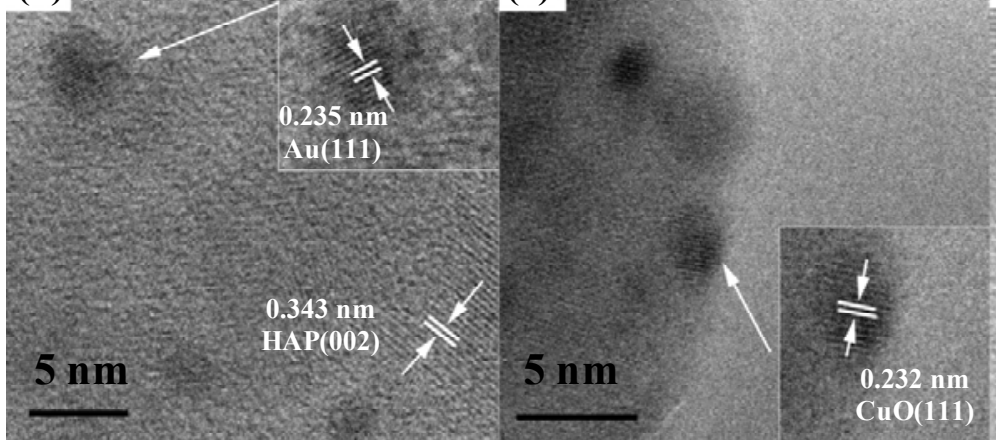

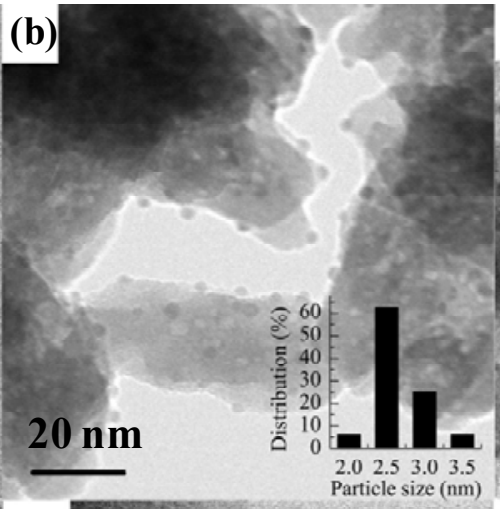

(e)
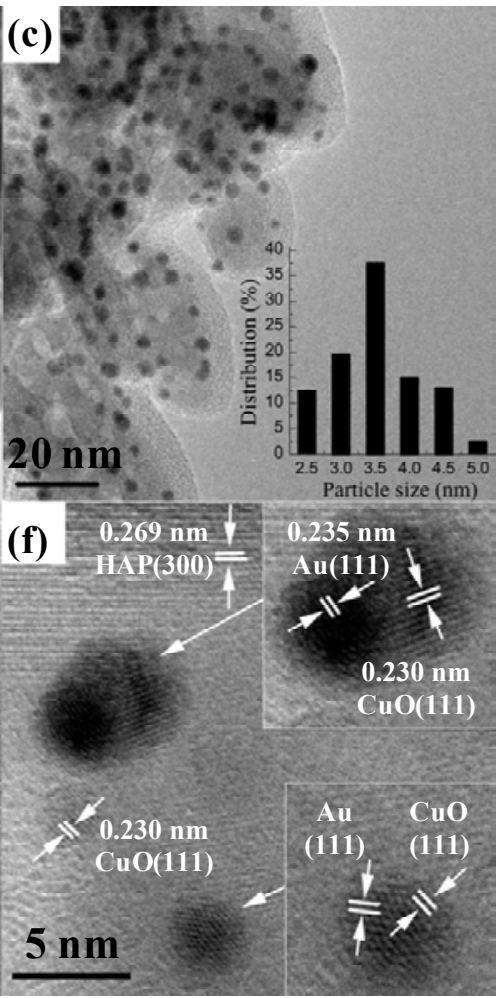

Fig. 2. TEM images and corresponding particle size distributions of Au/HAP (a), CuO-HAP (b), and Au/CuO-HAP (c); HRTEM images of Au/HAP (d), $\mathrm{CuO}-\mathrm{HAP}(\mathrm{e})$, and $\mathrm{Au} / \mathrm{CuO}-\mathrm{HAP}(\mathrm{f})$. 
might dope into the HAP network. When the solution of copper(II) chloride and phosphoric acid was added dropwise to the calcium hydroxide suspension at $80{ }^{\circ} \mathrm{C}$ (as described in the experimental section), copper hydroxide was more easily precipitated than copper phosphate, because the former is less soluble at $\mathrm{pH}=9.0$. As a result, large amounts of $\mathrm{CuO}$ NPs were generated when copper hydroxide decomposed at high temperature. Fig. 2(c) shows that $\mathrm{Au}$ and $\mathrm{CuO}$ NPs of average diameter $(3.5 \mathrm{~nm})$ are finely dispersed on the CuO-HAP support. Little NPs aggregation was observed, possibly because of the high surface area of the porous structure of CuO-HAP or the sinter-resistant properties of CuO. The HRTEM image of $\mathrm{Au} / \mathrm{CuO}$-HAP shows the presence of $\mathrm{CuO}$ NPs and bimetallic $\mathrm{Au}-\mathrm{CuO}$ NPs. The interplanar distance of $0.269 \mathrm{~nm}$ corresponds to the (300) crystal plane of the HAP support (Fig. 2(f)).

XPS was used to determine the surface chemical states of $\mathrm{Au}$ and $\mathrm{Cu}$ in the samples. Fig. 3 shows the $\mathrm{Au} 4 f$ and $\mathrm{Cu} 2 p_{3 / 2} \mathrm{XPS}$ profiles of $\mathrm{Au} / \mathrm{HAP}, \mathrm{Au} / \mathrm{CuO}-\mathrm{HAP}$, and $\mathrm{CuO}-\mathrm{HAP}$. The $\mathrm{Au} 4 f$ spectra of $\mathrm{Au} / \mathrm{HAP}$ and $\mathrm{Au} / \mathrm{CuO}-\mathrm{HAP}$ (Fig. 3(a)) show that the binding energies of $\mathrm{Au}$ in $\mathrm{Au} / \mathrm{HAP}$ at 87.5 and $83.8 \mathrm{eV}$ are attributable to $\mathrm{Au} 4 f_{5 / 2}$ and $4 f_{7 / 2}$, respectively, the $\mathrm{Au} 4 f_{5 / 2}$ and $4 f_{7 / 2}$ binding energies in $\mathrm{Au} / \mathrm{CuO}$-HAP shifted to 87.8 and 84.1 $\mathrm{eV}$, respectively. The $0.3 \mathrm{eV}$ positive shift for $\mathrm{Au} / \mathrm{CuO}-\mathrm{HAP}$ compared with $\mathrm{Au} / \mathrm{HAP}$ was probably caused by interactions between Au NPs and CuO NPs. After four runs of benzyl alcohol oxidation, the $\mathrm{Au}$ chemical state of the used $\mathrm{Au} / \mathrm{CuO}$-HAP was almost unchanged. The asymmetric $\mathrm{Cu} 2 p_{3 / 2}$ peaks in the spectra of fresh $\mathrm{Au} / \mathrm{CuO}-\mathrm{HAP}$ and $\mathrm{CuO}-\mathrm{HAP}$ can be fitted to two peaks, at 933.5 and $935.0 \mathrm{eV}$, which are attributed to the binding energies of $\mathrm{Cu} 2 p_{3 / 2}$ in $\mathrm{CuO}$ and copper phosphate, respectively [30,31]. The characteristic shake-up satellite peak at the higher binding energy of $944 \mathrm{eV}$ for $\mathrm{Cu}^{2+}$ also indicates that the main components were $\mathrm{Cu}^{2+}$ species. The peak-fitting results indicate that the atomic ratio of $\mathrm{Cu}$ from $\mathrm{CuO}$ to $\mathrm{Cu}$ from copper phosphate in both $\mathrm{CuO}-\mathrm{HAP}$ and $\mathrm{Au} / \mathrm{CuO}-\mathrm{HAP}$ was close to 4:1, i.e., in $\mathrm{Au} / \mathrm{CuO}-\mathrm{HAP}$ and $\mathrm{CuO}-\mathrm{HAP}, \mathrm{Cu}$ was mainly present in the $\mathrm{CuO}$ state, with a small amount of $\mathrm{Cu}$ doped into the HAP network; these results are consistent with the TEM images. However, in Fig. 3(b), the peak in the $\mathrm{Cu} 2 p_{3 / 2}$ spectrum of the used

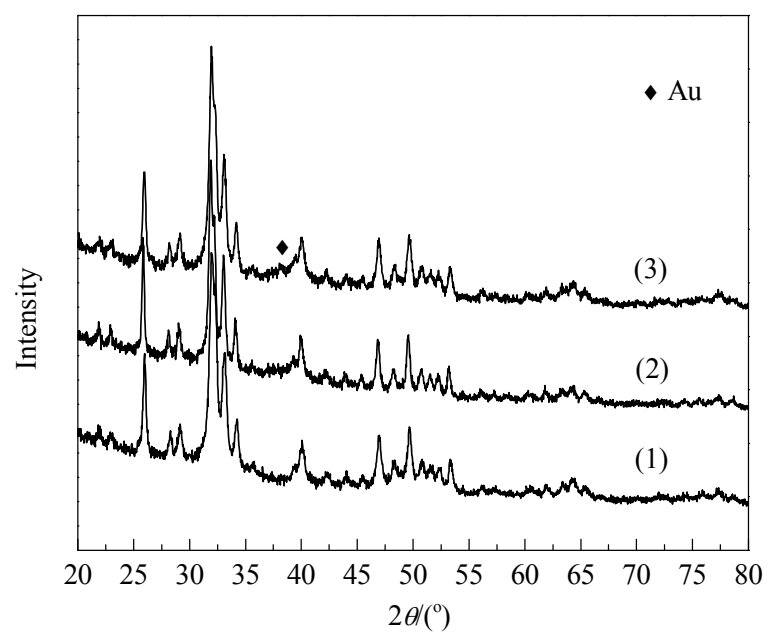

Fig. 4. XRD patterns of CuO-HAP (1), Au/HAP (2), and Au/CuO-HAP (3).

$\mathrm{Au} / \mathrm{CuO}-\mathrm{HAP}$ shifted from 933.6 to $933.0 \mathrm{eV}$, and was fitted to three peaks, at 935.0, 933.5, and $932.5 \mathrm{eV}$, which correspond to the binding energies of $\mathrm{Cu} 2 p_{3 / 2}$ in copper phosphate, $\mathrm{CuO}$, and $\mathrm{Cu}_{2} \mathrm{O}$, respectively. The weakened shake-up satellite peak also indicates that the $\mathrm{Cu}^{2+}$ was partially reduced. Area integration showed that about $50 \%$ of surface $\mathrm{Cu}$ was transformed into $\mathrm{Cu}_{2} \mathrm{O}$ in the used $\mathrm{Au} / \mathrm{CuO}-\mathrm{HAP}$. It is easy to see that $\mathrm{CuO}$ was partially reduced to $\mathrm{Cu}_{2} \mathrm{O}$ in the presence of benzyl alcohol under alkaline conditions; during this process, $\mathrm{CuO}$ could supply active oxygen for the reaction [28].

Fig. 4 shows the XRD patterns of CuO-HAP, Au/HAP, and $\mathrm{Au} / \mathrm{CuO}-\mathrm{HAP}$. The major diffraction peaks for $\mathrm{CuO}-\mathrm{HAP}$, $\mathrm{Au} / \mathrm{HAP}$, and $\mathrm{Au} / \mathrm{CuO}-\mathrm{HAP}$, at $2 \theta=25.9^{\circ}, 31.9^{\circ}, 33.1^{\circ}$, and $34.1^{\circ}$, are almost identical, and in good agreement with the typical HAP structure (PDF No. 09-0432). These results show that the prepared $\mathrm{CuO}-\mathrm{HAP}$ and HAP were stable during $\mathrm{Au}$ NPs loading, and the HAP structure was not changed by the small amount of $\mathrm{Cu}$ doping. Although the $\mathrm{Au}$ and $\mathrm{Cu}$ contents in $\mathrm{Au} / \mathrm{CuO}-\mathrm{HAP}$ were both $4 \%$, only a weak and broad diffraction peak at $2 \theta=38.2^{\circ}$, associated with the Au (111) plane, can be

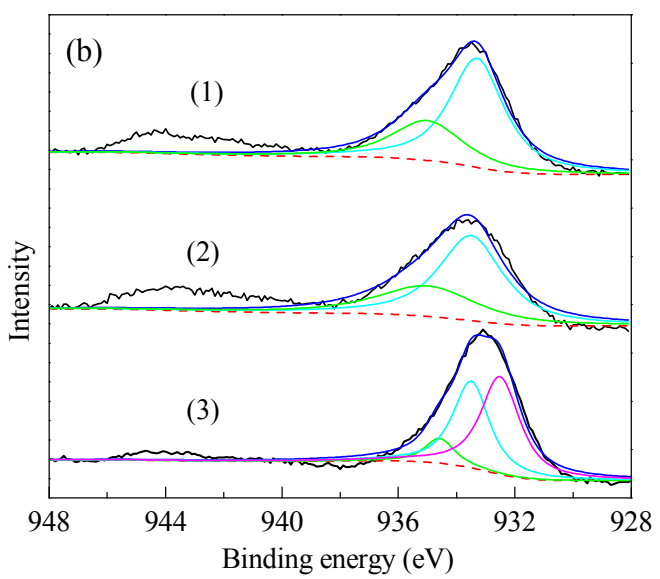

Fig. 3. (a) Au $4 f$ XPS profiles of Au/HAP (1), fresh Au/CuO-HAP (2), and used Au/CuO-HAP (3), and (b) $\mathrm{Cu} 2 p_{3 / 2}$ XPS profiles of CuO-HAP (1), fresh $\mathrm{Au} / \mathrm{CuO}-\mathrm{HAP}(2)$, and used Au/CuO-HAP (3). 
identified; this is attributed to the effect of the small finely dispersed $\mathrm{Au}$ and $\mathrm{CuO}$ NPs.

\subsection{Catalytic performance in benzyl alcohol oxidation}

In the aerobic oxidation of benzyl alcohol catalyzed by monometallic Au catalysts, by-products such as toluene, benzoic acid, and benzyl benzoate are easily formed [15,32]. Bimetallic Au catalysts have enhanced activity and selectivity in alcohol oxidation [18,27]. The catalytic performance of the $\mathrm{Au} / \mathrm{HAP}, \mathrm{CuO}-\mathrm{HAP}$, and $\mathrm{Au} / \mathrm{CuO}-\mathrm{HAP}$ catalysts in the aerobic oxidation of benzyl alcohol are summarized in Table 1 . When CuO-HAP was used, only $4.5 \%$ of benzyl alcohol was converted to benzaldehyde after reaction for $1.5 \mathrm{~h}$, indicating that this catalyst had low catalytic activity in this reaction. Under the same reaction conditions, Au/HAP exhibited higher catalytic activity, and $53.2 \%$ and $98.9 \%$ conversions of benzyl alcohol were achieved after 1 and $4 \mathrm{~h}$, respectively. However, the selectivity for benzaldehyde decreased from $96.2 \%$ to $91.4 \%$, and about $9 \%$ benzyl benzoate was generated as a by-product, because of over oxidation. Benzyl alcohol was quantitatively converted to benzaldehyde over $\mathrm{Au}-\mathrm{CuO} / \mathrm{HAP}$ after $1.5 \mathrm{~h}$, and the selectivity for benzaldehyde remained greater than $98.4 \%$, without over oxidation. The calculated turnover frequencies (TOFs) of $\mathrm{Au} / \mathrm{CuO}-\mathrm{HAP}$ and $\mathrm{Au} / \mathrm{HAP}$ were 548 and $460 \mathrm{~h}^{-1}$ respectively, indicating that $\mathrm{Au} / \mathrm{CuO}-\mathrm{HAP}$ had higher catalytic activity in the aerobic oxidation of benzyl alcohol. We suggest that the enhanced catalytic performance of $\mathrm{Au} / \mathrm{CuO}$-HAP in the aerobic oxidation of benzyl alcohol is the result of a synergistic effect between the supported $\mathrm{Au}$ and $\mathrm{CuO}$ NPs.

\subsection{Scope of Au/CuO-HAP-catalyzed alcohol oxidation}

The scope for the Au/CuO-HAP-catalyzed aerobic oxidation of alcohols was investigated. Table 2 lists the results for aerobic oxidation of various alcohols catalyzed by $\mathrm{Au} / \mathrm{CuO}-\mathrm{HAP}$. The oxidation of benzyl alcohol and its derivatives with electron-donating groups to the corresponding aldehydes (entries 1-3) was easier than the oxidation of benzyl alcohol with an

\section{Table 1}

Catalytic performance of $\mathrm{Au} / \mathrm{HAP}, \mathrm{CuO}-\mathrm{HAP}$, and $\mathrm{Au} / \mathrm{CuO}-\mathrm{HAP}$ in oxidation of benzyl alcohol.

\begin{tabular}{|c|c|c|c|c|c|c|c|}
\hline Catalyst & $\begin{array}{l}\mathrm{Au}^{\mathrm{a}} \\
(\%)\end{array}$ & $\begin{array}{l}\mathrm{Cu}^{\mathrm{a}} \\
(\%)\end{array}$ & $\begin{array}{l}\text { Size } \\
(\mathrm{nm})\end{array}$ & $\begin{array}{l}\text { Time } \\
\text { (h) }\end{array}$ & $\begin{array}{l}\text { Conver- } \\
\text { sion }^{\mathrm{b}} \\
(\%)\end{array}$ & $\begin{array}{l}\text { Benzalde- } \\
\text { hyde } \\
\text { selectivity } \\
(\%) \\
\end{array}$ & $\begin{array}{l}\text { TOF }^{c} \\
\left(\mathrm{~h}^{-1}\right)\end{array}$ \\
\hline \multirow[t]{2}{*}{ CuO-HAP } & - & 3.9 & 2.7 & 1.0 & 1.5 & 0 & - \\
\hline & & & & 1.5 & 4.5 & 100 & \\
\hline \multirow[t]{3}{*}{$\mathrm{Au} / \mathrm{HAP}$} & 4.3 & - & 3.8 & 1.0 & 53.2 & 96.2 & 460 \\
\hline & & & & 1.5 & 75.7 & 93.1 & \\
\hline & & & & 4.0 & 98.9 & 91.4 & \\
\hline \multirow[t]{2}{*}{$\mathrm{Au} / \mathrm{CuO}-\mathrm{HAP}$} & 4.7 & 3.7 & 3.5 & 1.0 & 95.9 & 98.6 & 548 \\
\hline & & & & 1.5 & 99.7 & 98.4 & \\
\hline
\end{tabular}

Reaction conditions: $3 \mathrm{mmol}$ benzyl alcohol, $1 \mathrm{mmol} \mathrm{K}_{2} \mathrm{CO}_{3}, 50 \mathrm{mg}$ catalyst, $10 \mathrm{~mL} p$-xylene, $20 \mathrm{~mL} / \mathrm{min} \mathrm{O}_{2}, 120^{\circ} \mathrm{C}$.

a The contents of $\mathrm{Au}$ and $\mathrm{Cu}$ were measured by AAS. b Products conducted by GC-FID. ' $\mathrm{TOF}$ value was calculated as: mol of benzyl alcohol converted at the first $15 \mathrm{~min} /(\mathrm{mol}$ of total loading of $\mathrm{Au} \times$ reaction time).
Table 2

Results for oxidation of various alcohols over $\mathrm{Au}-\mathrm{CuO} / \mathrm{HAP}$ in $p$-xylene.

\begin{tabular}{|c|c|c|c|c|c|}
\hline Entry & Substrate & $\begin{array}{c}\text { Conversion }{ }^{\mathrm{a}} \mathrm{A} \\
\text { (\%) }\end{array}$ & $\begin{array}{l}\text { Aldehyde/ketone } \\
\text { selectivitya (\%) }\end{array}$ & $\begin{array}{l}\text { Time } \\
\text { (h) }\end{array}$ & $\begin{array}{l}\mathrm{TOF}^{\mathrm{b}} \\
\left(\mathrm{h}^{-1}\right)\end{array}$ \\
\hline 1 & & 99.7 & 98.4 & 1.5 & 548 \\
\hline 2 & & 99.7 & $>99.9$ & 3.5 & 414 \\
\hline 3 & & 99.8 & 99.7 & 3.5 & 405 \\
\hline $4^{c}$ & & 94.5 & $>99.9$ & 7.0 & 119 \\
\hline 5 & & 89.8 & 97.5 & 9.0 & 99 \\
\hline 6 & & 99.6 & 99.5 & 4.0 & 254 \\
\hline 7 & & 99.9 & $>99.9$ & 1.5 & 536 \\
\hline
\end{tabular}

Reaction conditions: $3 \mathrm{mmol}$ alcohol, $1 \mathrm{mmol} \mathrm{K}_{2} \mathrm{CO}_{3}, 50 \mathrm{mg}$ $\mathrm{Au} / \mathrm{CuO}$-HAP catalyst, $10 \mathrm{~mL} p$-xylene, $20 \mathrm{~mL} / \mathrm{min} \mathrm{O}_{2}, 120^{\circ} \mathrm{C}$.

a Products conducted by GC-FID. ${ }^{\mathrm{b}} \mathrm{TOF}$ value was calculated as: mol of alcohol converted at the first $15 \mathrm{~min} /(\mathrm{mol}$ of total loading of $\mathrm{Au} \times$ reaction time). ${ }^{c} 0.1 \mathrm{~g} \mathrm{Au} / \mathrm{CuO}-\mathrm{HAP}$ catalyst.

electron-withdrawing group (entry 4). Although the catalytic activity in the reaction with 2-furanmethanol was low, the selectivity for furfuraldehyde was greater than $97.5 \%$ (entry 5). Cinnamyl alcohol and diphenylmethanol were also quantitatively converted to their corresponding aldehyde and ketone with high TOF values (entries 6 and 7).

\subsection{Reusability of $\mathrm{Au} / \mathrm{CuO}-\mathrm{HAP}$ catalyst}

Catalyst reusability is important in industry. As a result of aggregation, particle size enlargement, and support instability, the catalytic performance of heterogeneous $\mathrm{Au}$ catalysts in liquid-phase oxidation of alcohols deteriorate in recycling experiments [15,33,34]. The recycling performance of the $\mathrm{Au} / \mathrm{CuO}$-HAP catalyst in the oxidation of benzyl alcohol was investigated. Table 3 lists the benzyl alcohol conversion and selectivity for benzaldehyde over recycled $\mathrm{Au} / \mathrm{CuO}$-HAP at 120 ${ }^{\circ} \mathrm{C}$ after reaction for $1.5 \mathrm{~h}$. Under the same aerobic conditions, the catalytic performance of $\mathrm{Au} / \mathrm{CuO}$-HAP from the second to the fourth runs was almost unchanged, and the benzyl alcohol conversion and selectivity for benzaldehyde was above $95 \%$ and $99 \%$, respectively, i.e., similar to those with the fresh catalyst (the first run). The TEM image of $\mathrm{Au} / \mathrm{CuO}$-HAP after the fourth run (Fig. 5) shows that the Au particle size had not noticeably altered, most of the Au NPs were of size 2.5 to $4.5 \mathrm{~nm}$, and no aggregation was observed. The XPS results show that the chemical state of $\mathrm{Au}$ did not change and about $50 \%$ of surface $\mathrm{Cu}$ was transformed into $\mathrm{Cu}_{2} \mathrm{O}$ in the catalyst after the fourth run (see Fig. 3). The change in the surface $\mathrm{Cu}$ structure did not significantly affect the catalytic activity of the reused $\mathrm{Au} / \mathrm{CuO}-\mathrm{HAP}$, indicating that the activity was dominated by $\mathrm{Au}$, with a minor contribution from $\mathrm{CuO}$. $\mathrm{CuO}$ NPs on the HAP sur- 
Table 3

$\mathrm{Au} / \mathrm{CuO}-\mathrm{HAP}$ recycling experiments.

\begin{tabular}{lcc}
\hline Run number & $\begin{array}{c}\text { Conversion of } \\
\text { benzyl alcohol (\%) }\end{array}$ & $\begin{array}{c}\text { Benzaldehyde } \\
\text { selectivity (\%) }\end{array}$ \\
\hline 1st & 99.7 & 98.4 \\
2nd & 95.8 & 99.2 \\
3rd & 97.2 & 99.5 \\
4th & 96.3 & 99.2 \\
\hline
\end{tabular}

Reaction conditions: $3 \mathrm{mmol}$ benzyl alcohol, $1 \mathrm{mmol} \mathrm{K}_{2} \mathrm{CO}_{3}, 50 \mathrm{mg}$ $\mathrm{Au} / \mathrm{CuO}$-HAP catalyst, $10 \mathrm{~mL} p$-xylene, $20 \mathrm{~mL} / \mathrm{min} \mathrm{O}_{2}, 120^{\circ} \mathrm{C}, 1.5 \mathrm{~h}$.

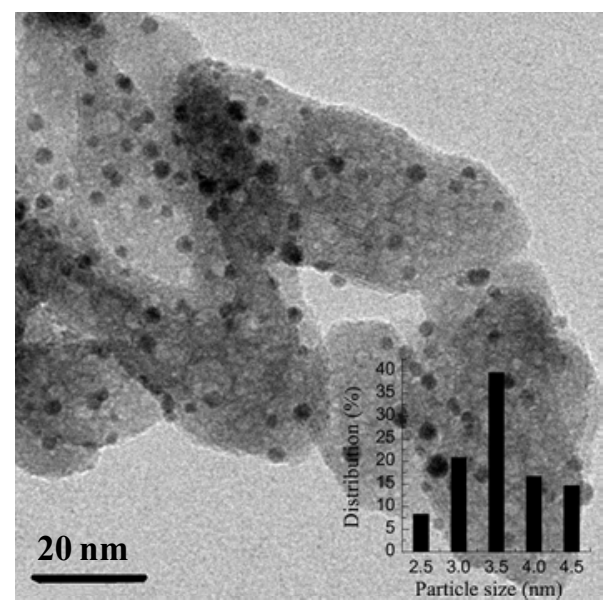

Fig. 5. TEM image and particle size distribution of $\mathrm{Au} / \mathrm{CuO}-\mathrm{HAP}$ catalyst after the fourth run.

face may act as anchors, protecting the Au NPs from aggregation.

\section{Conclusions}

A bimetallic catalyst, i.e., $\mathrm{Au} / \mathrm{CuO}-\mathrm{HAP}$, with an average particle diameter of $3.5 \mathrm{~nm}$ was prepared by a simple method and used in the liquid-phase aerobic oxidation of alcohols. The catalytic performance of $\mathrm{Au} / \mathrm{CuO}$-HAP in the aerobic oxidation of benzyl alcohol was better than that of monometallic Au/HAP and CuO-HAP catalysts, because of the bimetallic synergistic effect. Various aromatic alcohols were converted to their corresponding aldehydes or ketones over $\mathrm{Au} / \mathrm{CuO}$-HAP, with high catalytic activity and excellent selectivity. The $\mathrm{Au}$ NPs were anchored on the support by CuO NPs, and had excellent size stability. The prepared $\mathrm{Au} / \mathrm{CuO}$-HAP catalyst can be reused at least four times without loss of its activity.

\section{References}

[1] Sheldon R A, Kochi J K. Metal-Catalyzed Oxidations of Organic Compounds. New York: Academic Press, 1981

[2] Cossio F P, Lopez M C, Palomo C. Tetrahedron, 1987, 43: 3963

[3] Lee D G, Spitzer U A.J Org Chem, 1970, 35: 3589

[4] Menger. F M, Lee C. J Org Chem, 1979, 44: 3446

[5] Jefford C W, Wang Y.J Chem Soc, Chem Commun, 1988: 634

[6] Weerasiri K C, Gorden A E V. Tetrahedron, 2014, 70: 7962

[7] Sato K, Aoki M, Takagi J, Noyori R. J Am Chem Soc, 1997, 119: 12386

[8] Dhakshinamoorthy A, Alvaro M, Garcia H. ACS Catal, 2011, 1: 48

[9] Dun R R, Wang X G, Tan M W, Huang Z, Huang X M, Ding W Z, Lu X G. ACS Catal, 2013, 3: 3063

[10] Wang L, Meng X J, Xiao F S. Chin J Catal (王亮, 孟祥举, 肖丰收. 催化 学报), 2010, 31: 943

[11] Hong Y J, Yan X Q Liao X F, Li R H, Xu S D, Xiao L P, Fan J. Chem Commun, 2014, 50: 9679

[12] Gopiraman M, Ganesh Babu S, Khatri Z, Kai W, Kim Y A, Endo M, Karvembu R, Kim I S.J Phys Chem C, 2013, 117: 23582

[13] Haruta M, Yamada N, Kobayashi T, lijima S. J Catal, 1989, 115: 301

[14] Haruta M, Tsubota S, Kobayashi T, Kageyama H, Genet M J, Delmon B. J Catal, 1993, 144: 175

[15] Wang Z, Xu C L, Wang H F. Catal Lett, 2014, 144: 1919

[16] Wang L, Zhang W, Su D S, Meng X J, Xiao F S. Chem Commun, 2012, 48: 5476

[17] Kesavan L, Tiruvalam R, Ab Rahim M H, bin Saiman M I, Enache D I, Jenkins R L, Dimitratos N, Lopez-Sanchez J A, Taylor S H, Knight D W, Kiely C J, Hutchings G J. Science, 2011, 331: 195

[18] Enache D I, Edwards J K, Landon P, Solsona-Espriu B, Carley A F,

\section{Graphical Abstract}

Chin. J. Catal, 2015, 36: 1358-1364 doi: 10.1016/S1872-2067(15)60854-3

\section{Bimetallic synergistic $\mathrm{Au} / \mathrm{CuO}$-hydroxyapatite catalyst for aerobic oxidation of alcohols}

Tao Tian, Ying Liu, Xungao Zhang*

Wuhan University
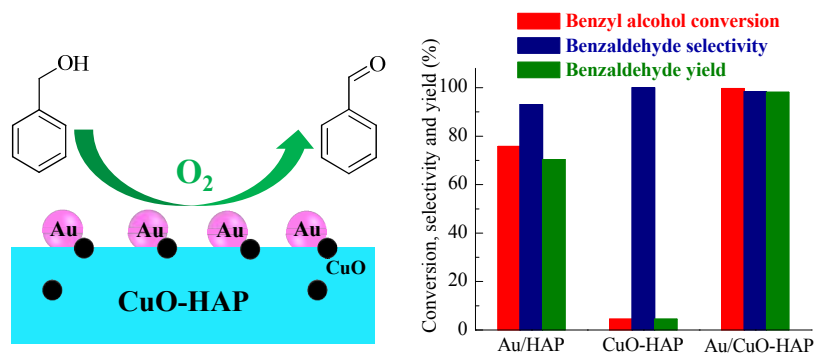

The catalytic activity and benzaldehyde selectivity of bimetallic $\mathrm{Au} / \mathrm{CuO}-\mathrm{HAP}$ in the oxidation of benzyl alcohol were better than those of monometallic $\mathrm{Au} / \mathrm{HAP}$ and $\mathrm{CuO} / \mathrm{HAP}$ catalysts. 
Herzing A A, Watanabe M, Kiely C J, Knight D W, Hutchings G J. Science, 2006, 311: 362

[19] Yang X, Chen D, Liao S J, Song H Y, Li Y W, Fu Z Y, Su Y L. J Catal, 2012, 291: 36

[20] Lopez-Sanchez J A, Dimitratos N, Glanville N, Kesavan L, Hammond C, Edwards J K, Carley A F, Kiely C J, Hutchings G J. Appl Catal A, 2011, 391: 400

[21] Zhao J G, Cheng X G, Wang L, Ren R F, Zeng J J, Yang H H, Shen B X. Catal Lett, 2014, 144: 2191

[22] Zhang H Y, Dai B, Wang X G, Li W, Han Y, Gu J J, Zhang J L. Green Chem, 2013, 15: 829

[23] Potemkin D I, Semitut E Yu, Shubin Yu V, Plyusnin P E, Snytnikov P V, Makotchenko E V, Osadchii D Y, Svintsiskiy D A, Venyaminov S A, Korenev S V, Sobyanin V A. Catal Today, 2014, 235: 103

[24] Neaţu Ş, Maciá-Agulló J A, Concepción P, Garcia H. J Am Chem Soc 2014, 136: 15969

[25] Yuan X, Zheng J W, Zhang Q, Li S R, Yang Y H, Gong J L. AIChE J, 2014, 60: 3300

[26] Jia Q Q, Zhao D F, Tang B, Zhao N, Li H D, Sang Y H, Bao N, Zhang X
M, Xu X H, Liu H.J Mater Chem A, 2014, 2: 16292

[27] Li W J, Wang A Q, Liu X Y, Zhang T. Appl Catal A, 2012, 433-434: 146

[28] Wang H, Fan W B, He Y, Wang J G, Kondo J N, Tatsumi T. J Catal, 2013, 299: 10

[29] Zanella R, Giorgio S, Shin C H, Henry C R, Louis C. J Catal, 2004, 222: 357

[30] Wen C, Cui Y Y, Chen X, Zong B N, Dai W L. Appl Catal B, 2015, 162: 483

[31] Moulder J F, Stickle W F, Sobol P E, Bomben K D. Handbook of $\mathrm{X}$-ray Photoelectron Spectroscopy. Minnesota: Physical Electronics, 1995

[32] Wang L C, He L, Liu Q, Liu Y M, Chen M, Cao Y, He H Y, Fan K N. Appl Catal A, 2008, 344: 150

[33] Li X, Zheng J M, Yang X L, Dai W L, Fan K N. Chin J Catal (李媡, 郑嘉 旻,杨新丽,戴维林,范康年. 催化学报), 2013, 34: 1013

[34] Hallett-Tapley G L, Silvero M J, Bueno-Alejo C J, González-Béjar M, McTiernan C D, Grenier M, Netto-Ferreira J C, Scaiano J C. J Phys Chem C, 2013, 117: 12279

\title{
氧化铜修饰羟基磷灰石负载金对醇类需氧氧化的双金属协同催化
}

\author{
田 涛, 刘 英, 张勋高* \\ 武汉大学化学与分子科学学院, 湖北武汉 430072
}

\begin{abstract}
摘要: 采用均匀沉积-沉淀法制备了氧化铜修饰羟基磷灰石负载金催化剂( $\mathrm{Au} / \mathrm{CuO}-\mathrm{HAP})$, 并用原子吸收光谱、 $\mathrm{N}_{2}$ 吸附脱附、X射 线粉末衍射、透射电镜和X射线光电子能谱等方法对催化剂结构和形貌进行了表征. 考察了催化剂对醇类液相需氧氧化的催化性 能. 与单金属 $\mathrm{Au} / \mathrm{HAP}$ 或 $\mathrm{CuO}-\mathrm{HAP}$ 相比较, 双金属 $\mathrm{Au} / \mathrm{CuO}-\mathrm{HAP}$ 对苯甲醇氧化的催化活性和苯甲醛的选择性有显著提高, $120^{\circ} \mathrm{C} 反$ 应 $1.5 \mathrm{~h}$, 苯甲醇的转化率和苯甲醛的选择性分别达到 $99.7 \%$ 和 $98.4 \%$. 在 $\mathrm{Au} / \mathrm{CuO}-\mathrm{HAP}$ 的催化下, 其它类型的芳香醇均可高选择性转 化为相应的醛或酮. $\mathrm{Au} / \mathrm{CuO}-\mathrm{HAP}$ 催化剂有很好的稳定性和可回收性,4次回收后,其催化活性没有明显变化.
\end{abstract}

关键词: 多相催化; 金-铜双金属催化剂; 醇类的需氧氧化; 羟基磷灰石; 重复使用性

收稿日期: 2015-02-10. 接受日期：2015-03-27. 出版日期: 2015-08-20.

*通讯联系人. 电话/传真: (027)68752136; 电子信箱: xgzhang66@whu.edu.cn

基金来源：湖北省自然科学基金(2013CFB291).

本文的英文电子版由Elsevier出版社在ScienceDirect上出版(http://www.sciencedirect.com/science/journal/18722067). 